\title{
Peningkatan hasil belajar tematik muatan IPA melalui model Problem Based Learning kelas 5 SDN Pajomblangan, Kedungwuni
}

\author{
Wikriyah \\ SDN Pajomblangan, Kecamatan Kedungwuni kabupaten Pekalongan
}

\begin{tabular}{|c|c|}
\hline Article Info & ABSTRACT \\
\hline Article history: & \multirow{4}{*}{$\begin{array}{l}\text { The low learning outcomes of thematic science content at SDN } \\
\text { Pajomblangan are due to the inactivity of students in participating in } \\
\text { learning. For this reason, this type of research was conducted using } \\
\text { classroom action research (CAR). This study aims to describe the steps in } \\
\text { implementing the Problem Based Learning learning model and to find out the } \\
\text { improvement in learning outcomes for class } 5 \text { science content. Data } \\
\text { collection techniques used test techniques and non-test (observation) } \\
\text { techniques. The analysis technique uses a quantitative descriptive technique. } \\
\text { The results showed that the application of the Problem Based Learning } \\
\text { model was able to improve student learning outcomes and activeness. The } \\
\text { increase in learning outcomes showed that in the pre-cycle the student's level } \\
\text { of completeness was } 48 \% \text {, for the first cycle the completeness level was } \\
71 \% \text {, and the second cycle the completeness level was } 90 \% \text {. While the } \\
\text { increase in student activity in the pre-cycle is } 50 \% \text {, for the first cycle the } \\
\text { student activity level is } 68 \% \text {, and the second cycle the student activity level } \\
\text { is } 87 \% \text {. Based on the results of the study, it can be concluded that the } \\
\text { Problem Based Learning learning model can improve learning outcomes and } \\
\text { student activity. }\end{array}$} \\
\hline $\begin{array}{l}\text { Received : } 30 \text { Agustus } 2021 \\
\text { Revised : } 21 \text { September } 2021 \\
\text { Accepted : } 27 \text { September } 2021\end{array}$ & \\
\hline & \\
\hline & \\
\hline
\end{tabular}

(*) Corresponding Author:

wiwiktalun2017@gmail.com

How to Cite: Wikriyah, W (2021). Peningkatan hasil belajar tematik muatan ipa melalui model Problem Based Learning kelas 5 SDN Pajomblangan, Kedungwuni. Action Research Journal, 1(1): 88-93.

\section{PENDAHULUAN}

Pendidikan merupakan suatu proses belajar yang dilakukan seseorang guna menghasilkan perubahan pada diri orang. Perubahan yang terjadi dapat berupa perubahan kognitif serta perubahan terhadap sikap serta perilaku dalam kehidupan sehari-hari. Purba \& Yusnadi (2014) menjelaskan pendidikan dapat diartikan sebagai proses kegiatan mengubah perilaku individu ke arah kedewasaan dan kematangan. Peranan pendidikan pada era globalisasi saat ini sangatlah penting, dimana pendidikan menjadi faktor utama dalam meningkatkan kualitas sumber daya manusia yang lebih baik, oleh karena itu saat ini banyak metode/strategi pembelajaran, fasilitas belajar yang bermunculan dengan tujuan untuk menarik minat belajar siswa (Aji \& Mediatati, 2021; Santiani, Sudana, \& Tastra, 2017). Upaya-upaya yang dilakukan pemerintah sudah merambah hampir ke semua komponen pendidikan seperti penambahan jumlah buku buku pelajaran, peningkatan kualitas guru, pembaharuan kurikulum dan peningkatan kualitas pembelajaran yang mencakup pembaharuan dalam model, metode, pendekatan dan media guna mengoptimalkan kualitas pembelajaran.

Berdasarkan pengamatan terhadap kegiatan pembelajaran muatan IPA pada pembelajaran tematik siswa kelas 5 SDN Pajomblangan ditemukan masalah dalam proses pembelajarannya. Pertama, ketika guru menyampaikan materi pembelajaran terdapat siswa tidak memperhatikan dengan baik. Hampir setengah dari jumlah keseluruhan siswa kurang antusias dan kurang fokus dalam mengikuti pembelajaran. Kedua, model dan metode yang digunakan dalam pembelajaran kurang melibatkan siswa untuk berpartisipasi aktif dan interaktif selama 
kegiatan pembelajaran berlangsung. Ketiga, siswa kurang terlibat dalam pembelajaran. Aktivitas belajar yang belum optimal dapat berdampak pada hasil belajar tematik muatan IPA yang cenderung rendah. Berdasarkan data nilai ulangan harian IPA kondisi awal, dari 21 siswa terdapat 52\% siswa tingkat tuntas. Dari hasil persentase menunjukkan bahwa peserta didik yang tidak tuntas lebih banyak dibandingkan peserta didik yang sudah tuntas. Artinya hasil belajar tematik muatan IPA belum maksimal dan cenderung rendah.

Semua itu menunjukkan bahwa guru harus selalu mengadakan perbaikan dalam pembelajarannya, agar masalah kesulitan belajar siswa dapat diatasi, peneliti ingin melakukan perbaikan dengan cara yang lebih baik dengan menggunakan model pembelajaran yang berbasis masalah pada siswa kelas $\mathrm{V}$ dan ini model yang paling tepat untuk meningkatkan hasil belajar sehingga hasil belajar siswa mencapai tujuan yang diharapkan. Problem based learning adalah seperangkat model mengajar yang menggunakan masalah sebagai fokus untuk mengembangkan keterampilan pemecahan masalah, materi, dan pengaturan diri (Eggen \& Kauchak, 2012; Wati, 2014; Nuraini, 2017). Model pembelajaran Problem Based Learning adalah salah satu model pembelajaran yang sangat ideal diterapkan dalam pembelajaran IPA. Dengan topik IPA yang cukup luas dan desain tugas mengarah pada kegiatan metode ilmiah, diharapkan siswa dan kelompoknya dapat saling memberi kontribusi berdasarkan pengalaman sehari-hari, (Rusman, 2010). Menurut Sariadi (2014) dan Safrida\& Kistian (2020), PBL merupakan suatu model pembelajaran yang titik tolak utamanya adalah masalah dan cara penyelesaiannya. Selanjutnya, Harjono (2019) menjelaskan model Problem Based Learning merupakan model pembelajaran yang melibatkan siswa dalam memecahkan masalah nyata. Berdasarkan pendapat ahli dapat disimpulkan bahwa Problem Based Learning merupakan model pembelajaran yang berbasis masalah kemudian melibatkan siswa untuk mengatasi serta menyelesaikan masalah dalam kehidupan nyata. Penerapan model Problem Based Learning yaitu siswa diminta untuk terlibat secara aktif dalam pemecahan masalah yang dilakukan melalui tahap-tahap metode ilmiah sehingga siswa dapat mem- pelajari pengetahuan yang berhu- bungan dengan masalah tersebut dan siswa dapat mengembangkan keteram- pilan pemecahan masalah (Wulandari, 2012; Novitasari \& Anugraheni, 2017; Yuafian \& Astuti, 2020).

Berdasarkan uraian di atas, maka tujuan penelitian yang ingin dicapai yaitu: 1) Menerapkan model problem based learning untuk keaktifan siswa kelas 5 SDN Pajomblangan. 2) Menerapkan model problem based learning untuk meningkatkan hasil belajar pada muatan IPA siswa kelas 5 SDN Pajomblangan.

\section{METODE PENELITIAN}

Jenis penelitian ini menggunakan Penelitian Tindakan Kelas (PTK). PTK merupakan bentuk penelitian dengan mengunakan data kualitatif dan kuantitatif. PTK dilakukan oleh guru sendiri yang hasilnya dapat dimanfaatkan sebagai alat untuk pengembangan dan perbaikan pembelajaran. PTK ini dilakukan dengan 2 siklus. Masing- masing siklus terdiri dari tiga pertemuan. Tiap siklus terdiri dari empat kegiatan, yakni perencanaan, tindakan, observasi dan refleksi.

Sampel pada penelitian ini adalah seluruh siswa kelas 5 SDN Pajomblangan. Instrumen penelitian berupa lembar observasi dan butir-butir soal hasil belajar muatan IPA. Lembar observasi adalah lembar yang digunakan untuk mengetahui keaktifan siswa dan proses pembelajaran yang dilaksanakan oleh guru. Sedangkan soal yang digunakan adalah soal tes tertulis untuk mengetahui hasil belajar. Teknik analisis data yang digunakan adalah teknik analisis deskriptif kunalitatif. Data hasil penelitian dibandingkan dari kondisi pra siklus, siklus I dan siklus II untuk mengetahui meningkatnya hasil belajar. Data hasil tes dan observasi akan dianalisis dengan cara menghitung persentase secara klasikal. Keberhasilan penelitian dilihat dari jumlah siswa yang mampu menyelesaikan atau minimal $75 \%$ sekurang-kurangnya $85 \%$ dari jumlah siswa yang ada di kelas tersebut. 


\section{HASIL PENELITIAN}

\section{Proses Pembelajaran Siklus I}

Proses pembelajaran yang dilakukan dengan menerapkan model Problem Based Learning (PBL). Untuk pertama kali pelaksanaan pembelajaran model PBL tidak dipungkiri beberapa siswa mengalami kesulitan dalam pembelajaran. Beberapa siswa mengalami kesulitan dalam menemukan solusi untuk memecahkan masalah. Pembelajaran pada siklus I diperoleh hasil bahwa aktivitas keaktifan siswa mendengarkan penjelasan guru, bertanya, menjawab maupun berpendapat dalam proses pembelajaran mengalami peningkatan dibandingkan hasil pra tindakan. Hasilnya menunjukkan bahwa keaktifan siswa dalam pembelajaran sebesar $68 \%$, naik $18 \%$ dibandingkan keaktifan siswa saat pra tindakan. Pembelajaran dengan model Problem Based Learning (PBL) melatih siswa untuk berpikir dalam menemukan solusi untuk menyelesaikan suatu masalah. Dalam proses tersebut melatih siswa belajar mandiri dan aktif terlibat dalam kegiatan pembelajaran. Siswa juga masih malu ketika mempresentasikan hasil laporan pekerjaannya. Kegiatan pembelajaran yang dilakukan pada siklus I, dengan menerapkan model Problem Based Learning (PBL) dapat meningkatkan hasil belajar siswa. Persentase siswa yang dikategorikan tuntas belajar pengalami peningkatan yaitu $23 \%$ yang semula $48 \%$ menjadi $71 \%$ atau sebanyak 15 siswa tuntas belajar pada siklus I. Hasil belajar siswa secara klasikal tergolong sedang dengan perolehan rata-rata sebesar 70,33. Meskipun terdapat peningkatan hasil belajar, perlu dilakukan perbaikan karena guru kurang memperhatikan siswa yang mengalami kesulitan dalam pembelajaran. Perbaikan ini dimaksudkan supaya pembelajaran yang dilaksanakan dapat lebih maksimal. Untuk lebih jelasnya dapat dilihat pada Tabel 1.

Tabel 1. Hasil Belajar pada Siklus I

\begin{tabular}{|c|c|c|c|c|}
\hline & \multicolumn{2}{|c|}{ Pratindakan } & \multicolumn{2}{|c|}{ Siklus I } \\
\hline & Jumlah Siswa & Persentase $(\%)$ & Jumlah Siswa & Persentase $(\%)$ \\
\hline Tuntas & 10 & 48 & 15 & 71 \\
\hline Belum Tuntas & 11 & 52 & 6 & 29 \\
\hline
\end{tabular}

Berdasarkan hasil belajar pada siklus I, dapat disimpulkan bahwa persentase siswa yang tuntas mengalami peningkatan, namun siklus I belum dikatakan berhasil karena dalam penelitian ini indikator keberhasilannya adalah $71 \%$ dari jumlah siswa

\section{Proses Pembelajaran Siklus II}

Hasil observasi pada siklus II menunjukkan peningkatan dibandingkan pada siklus I. Pembelajaran pada siklus II diperoleh hasil bahwa aktivitas keaktifan siswa mendengarkan penjelasan guru, memberikan berpendapat atau jawaban dalam proses pembelajaran mengalami peningkatan. Namun pada pembelajaran siklus II ketika guru memberikan kesempatan bertanya siswa masih malu untuk bertanya. Hasilnya menunjukkan bahwa keaktifan siswa dalam pembelajaran sebesar $87 \%$, naik $19 \%$ dibandingkan keaktifan siswa siklus I sebesar $68 \%$. Pembelajaran dengan model Problem Based Learning (PBL) melatih siswa untuk berpikir dalam menemukan solusi untuk menyelesaikan suatu masalah. Dalam proses tersebut melatih siswa belajar mandiri dan aktif terlibat dalam kegiatan pembelajaran. Pada siklus II guru sudah memperhatikan siswa yang mengalami kesulitan dalam mengikuti pembelajaran. Kegiatan pembelajaran yang dilakukan pada siklus II, dengan menerapkan model Problem Based Learning (PBL) dapat meningkatkan hasil belajar siswa. Persentase siswa yang dikategorikan tuntas belajar mengalami peningkatan sebesar $19 \%$ yang semula $71 \%$ menjadi $90 \%$. Selain itu pada siklus II nilai rata-rata siswa juga mengalami peningkatan sebesar 10,2, yang semula ratarata siswa 70,3 pada siklus II nilai rata-rata sebesar 80,5. Hasil belajar secara keseluruhan dapat dilihat pada Tabel 2. 
Tabel 1. Hasil belajar pada Siklus II

\begin{tabular}{lcccccc}
\hline & \multicolumn{2}{c}{ Pratindakan } & \multicolumn{2}{c}{ Siklus I } & \multicolumn{2}{c}{ Siklus I } \\
\hline & Jumlah & Persentase & Jumlah & Persentase & Jumlah & Persentase \\
& Siswa & $(\%)$ & Siswa & $(\%)$ & Siswa & \begin{tabular}{c}
$(\%)$ \\
\hline Tuntas
\end{tabular} \\
\hline & 10 & 48 & 15 & 71 & 19 & 90 \\
Belum Tuntas & 11 & 52 & 6 & 29 & 2 & 10 \\
\hline Rerata nilai & & 60,4 & \multicolumn{2}{c}{70,33} & \multicolumn{2}{c}{80,5} \\
\hline
\end{tabular}

Berdasarkan hasil belajar pada siklus II di atas dapat disimpulkan bahwa keberhasilan bahwa terdapat peningkatan nilai rata-rata siswa dari pratindakan hingga siklus II. Penelitian ini dikatakan berhasil karena indikator keberhasilannya lebih dari $85 \%$ dari jumlah siswa yang memperoleh nilai lebih dari KKM. Namun secara klasikal masih terdapat 2 siswa yang belum dinyatakan tuntas belajar.

\section{PEMBAHASAN}

Penelitian tindakan kelas ini menekankan pada usaha perbaikan untuk dapat meningkatkan hasil belajar IPA pada siswa kelas 5 SDN Pajomblangan dengan menggunakan model pembelajaran Problem Based Learning (PBL). Model PBL menuntut siswa untuk membangun pengetahuan siswa sendiri dengan memecahkan masalah yang siswa hadapi (Harjono, 2019; Safrida \& Kistian, 2020). Dalam pembelajaran siswa diorientasikan kedalam masalah, secara berkelompok siswa bersama-sama untuk mencari jalan keluar dalam masalah. Setelah siswa mampu memecahkan masalah siswa mempresentasikan hasil penelitian kelompok di depan kelas. Kelompok lain menanggapi saat ada temannya yang sedang presentasi. Guru didalam kelas menjadi fasilitator jadi siswa yang mendominasi pembelajaran bukan pembelajaran berpusat pada guru (Rusman, 2014). Pada akhir pembelajaran guru memberikan evaluasi untuk mengetahui sejauhmana siswa dapat memahami tentang materi dipelajari. Gambar 1 menunjukkan bahwa hasil belajar dan rerata nilai siswa pada kondisi awal, siklus I dan siklus II mengalami peningkatan. Begitu juga untuk keaktifan siswa dari kondisi awal, siklus I dan siklus II mengalami peningkatan.

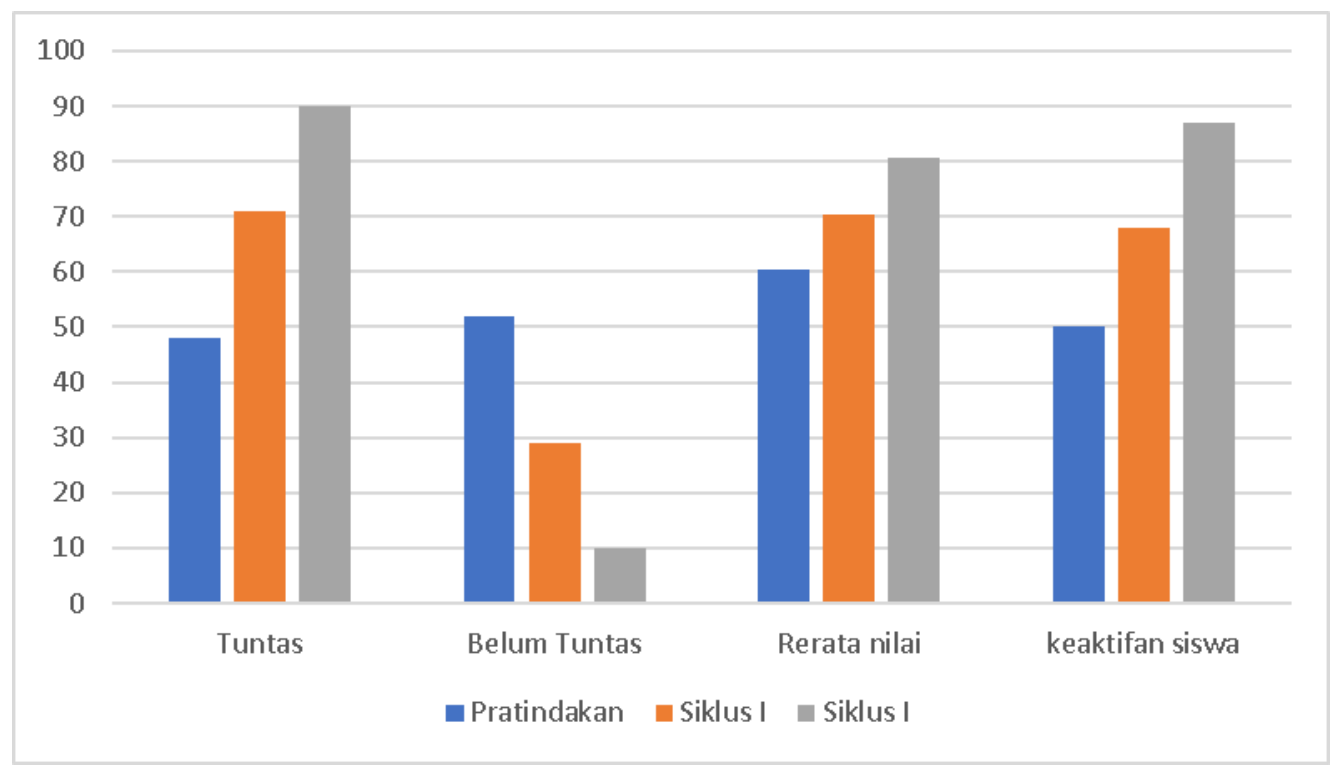

Gambar 1. Perbandingan Pra Tindakan, Siklus I dan Siklus II

Peningkatan hasil belajar dapat terjadi karena dengan menggunakan model PBL siswa lebih mudah memahami pembelajaran, meningkatkan aktivitas siswa karena siswa sendiri yang membangun pengetahuannya dan lebih mudah dimengerti karena mengaplikasikan pengetahuan yang mereka miliki dengan dunia nyata. Sejalan dengan pendapat dari Sanjaya (Wulandari 
2012) menyebutkan bahwa PBL memiliki beberapa keunggulan, antara lain: 1) PBL dapat meningkatkan aktivitas pembelajaran, 2) PBL dapat mengembangkan kemampuan berpikir kritis, 3) PBL dapat memberikan kesempatan kepada siswa untuk mengaplikasikan pengetahuan yang mereka milik dalam dunia nyata, 4) PBL dapat mengembangkan minat siswa untuk belajar secara terus-menerus sekalipun belajar pada pendidikan formal telah berakhir (Novitasari \& Anugraheni, 2017).

Hasil penelitian yang sejalan dengan penelitian ini dilakukan oleh Aji \& Mediatati (2021), Sariadi (2014), Safrida \& Kistian (2020) Yuafian \& Astuti (2020) dan Wati (2014) menunjukkan bahwa adanya keberhasilan dalam proses pembelajaran dengan menggunakan model Problem Based Learning (PBL) sehingga dapat meningkatkan hasil belajar IPA siswa kelas 5 SD. Penelitian kali ini juga terbukti dapat meningkatkan hasil belajar IPA kelas 5 SDN Pajomblangan. Dengan menggunakan model ini siswa akan lebih semangat dan antusias dalam mengikuti pembelajaran, siswa dapat lebih aktif dalam pembelajaran karena siswa membangun pengetahuannya sendiri dari apa yang mereka pelajari, jadi daya serap siswa terhadap materi yang diajarkan juga lebih baik.

\section{SIMPULAN}

Berdasarkan hasil penelitian dan analisis data mengenai peningkatan hasil belajar dan keaktifan siswa siswa di 5 SDN Pajomblangan melalui penerapan model pembelajaran Problem Based Learning (PBL). Pada siklus I dan siklus II pembelajaran PBL dilakukan dengan langkah-langkah sebagai berikut: 1) orientasi siswa kepada masalah yaitu tentang cahaya dan sifat-sifatnya, 2) mengorganisasi siswa untuk belajar, 3) guru membimbing penyelidikan individual maupun kelompok, 4) siswa mengembangkan dan menyajikan hasil karya, 5) menganalisis dan mengevaluasi proses pemecahan masalah dalam pembelajaran IPA.

\section{DAFTAR PUSTAKA}

Aji, S. B., \& Mediatati, N. (2021). Penerapan Problem Base Learning Untuk Meningkatkan Hasil Belajar IPA di Sekolah Dasar. Edukatif: Jurnal Ilmu Pendidikan, 3(5), 2734-2740.

Eggen, P. \& Kauchak, D. (2012). Strategi dan Model Pembelajaran Mengajarkan Konten dan Keterampilan Berpikir. Jakarta: Indeks

Gunawan, I. K. A., Rati, N. W., \& Sudatha, I. G. W. (2021). Model Problem Based Learning (PBL) Meningkatkan Hasil Belajar IPA Siswa Kelas IV SD. Jurnal Pedagogi dan Pembelajaran, 4(1).

Harjono, N. (2019). Peningkatan kemampuan berpikir kritis dan hasil belajar tematik muatan ipa melalui model problem based learning kelas 5 SD. Jurnal Basicedu, 3(1), 16-20.

Novitasari, R. A., \& Anugraheni, I. (2017). Peningkatan Kreativitas dan Hasil Belajar IPA Siswa Kelas 5 SD Taruna Bangsa melalui Pendekatan Problem Based Learning. Jurnal Handayani PGSD FIP Unimed, 7(2), 77-83.

Nuraini, F. (2017). Penggunaan Model Problem Based Learning (PBL) untuk Meningkatkan Hasil Belajar IPA Siswa Kelas 5 SD. E-Jurnal mitra pendidikan, 1(4), 369-379.

Purba, E. \& Yusnadi. (2014). Filsafat Pendidikan. Medan: Unimed Press.

Rusman. (2014). Model-model Pembelajaran. Mengembangkan Profesionalisme Guru. Jakarta: PT raja Grafindo Persada.

Safrida, M., \& Kistian, A. (2020). Penerapan model pembelajaran problem based learning (PBL) untuk meningkatkan hasil belajar IPA Kelas V SD Negeri Peureumeue Kecamatan Kaway XVI. Bina Gogik: Jurnal Ilmiah Pendidikan Guru Sekolah Dasar, 7(1).

Santiani, N. W., Sudana, D. N., \& Tastra, I. D. K. (2017). Pengaruh Model Pembelajaran Problem Based Learning Berbantuan Media Konkret Terhadap Hasil Belajar IPA Siswa Kelas V SD. Mimbar PGSD Undiksha, 5(2).

Sariadi, N. K. (2014). Penerapan Model Pembelajaran Berbasis Masalah Untuk Meningkatkan Hasil Belajar IPA kelas V SD. Jurnal: PGSD Universitas Pendidikan Ganesha Singaraja 
Wati, N. I. (2014). Penerapan Model Pembelajaran Berbasis Masalah Untuk Meningkatkan Hasil Belajar IPA Siswa di Kelas V SD Negeri Pasuruhan Pati. Jurnal: PGSD-FKIPUniversitas Muria Kudus.

Wulandari, E. (2012). Penerapan Model PBL (Problem Based Learning) pada Pembelajaran IPA Siswa Kelas V SD. Jurnal: FKIP-Universitas Sebelas Maret.

Yuafian, R., \& Astuti, S. (2020). Peningkatan Hasil Belajar Siswa Menggunakan Model Pembelajaran Problem Based Learning (Pbl). JRPD (Jurnal Riset Pendidikan Dasar), 3(1), 17-24. 